https://doi.org/10.3126/pragya.v7i1.35252

\title{
The Impact of Media Advertisement on Consumers Purchasing Behaviour
}

\author{
Sah Gunja Kumari \& Karki Sangita
}

\begin{abstract}
Marketers spend a massive amount on various media platforms to influence consumer behavior. Advertisement on every media platform has a different component that involves the Consumer for different purposes. Technological innovation has led to changes in Consumer's media habits. Hence, a deeper understanding of advertisements on various media platforms,and their implications on consumer behavior needs to be established. This study aims to examine the relationship between advertisement dimensions such as printing, broadband, outdoor and social media, and consumerpurchasingbehavior. Data were collected with the help of a structured questionnaire by email and direct interviews with the consumers located in Kathmandu valley. The findings revealed that the advertisement media dimensions had a strong correlation with consumer purchasing behavior. It also indicated that printing, outdoor and social media were statistically significant, and broadband media were found to be statistically insignificant with consumers' purchase behavior.
\end{abstract}

Keywords: Advertisement dimensions, Consumers, Media advertisements, Purchasingbehavior,

\section{Background}

In this $21^{\text {st }}$ century, nobody can escape from the extensive influence of mass media. The world has become a global village. In this age, messages can be delivered by different media dimensions that consist of newspapers, magazines,radio, television, mail order, direct mail, outdoor displays, and various social media. Among the complete marketing tools, the advertising media is distinctive for the continuing impact on the observer's mind as its effect is broader(Ismail, 2016).

Advertisement is the primary source of communication tools. It is the major part of Promotion Mix and is one of the essential components 4P's in the Marketing Mix. Marketing mix components include Product, Price, Place, and Promotion.Advertising is a means of the Promotion mix strategy that helps create product awareness in the market that eventually influencesconsumer purchasing decisions (Kotler \& Keller, 2006).

Now a day's advertisement is an excellent source for promoting business in the whole world. This study plans to explore the importanceof various media advertisements on consumer behavior stages such as Print media, broadband media, outdoor media, and 
social media. The consumers anticipate information from various media such as newspapers, magazines, brochures, booklets as a printing media, television, radio as a broadcast media, billboards, kiosks, events, sponsorship as an outdoor media, and Twitter, Facebook, website ads as a social media. Different media's characteristics of long-term effects on consumer purchase behavior (Deshpande et al., 2019; Sama, 2019).

Advertisement media has become an essential means for global marketing communicationsand is commanding a larger share of advertising budgets. Therefore, the value of advertising on different advertisement media is of great interest to organizations. It is also important to businessperson, managers, andacademics.

The questions here arise how consumersbehave on the basis of advertisement media. From what source they get information about product or brand and what factors affect them to choose the product? These are burning questions of Nepalese market. However, little attempt has been made so far to answer the questions. Some major research questions are:

- Are there any relationship between printing, broadband, outdoor and social media and purchase behavior?

- What are the major influential advertising media on consumer behavior?

On the basis of burning issue some major objectives are as follows:

- To examine the relationship betweenprinting, broadband, outdoor and social media and purchase behavior.

- To identify major influential advertisement dimensions that influence on consumer behavior.

The responses for this study were solicited from only a few areas of Kathmandu valley. So, future research needs to be done to generalize. This study is only limited to exploring the relationship printing, broadband, outdoor and social media and consumer purchasing behavior.

\section{Literature Review}

Rajagopal (2011) aimed to analyze the impact of radio advertisements on urban commuters on buying behavior in retail stores. The sample respondents for the study frequently commute to their workplacesfrom the residential areas of the southern, northern, and suburban habitats in Mexico City. Datawere collected using personal interviews during 2007-2009 in different festival seasons. The result revealed that the buying behavior of urban consumer at retail stores in responseto radio advertisements is highly influenced by the physical, cognitive, and economic variables.

Prasad \& Jha (2014)studied to identify the significant cues for a purchase decision. They explained various buying decision models that are most valuable in marketing. They had focused on how a marketer can improve methods to convince the customers effectively. 
Ismail (2016) stated that the objective was to determine how muchadvertisement affects the consumer's buying behavior regarding FMCGs. Data were analyzed using statistical techniques such asdescriptive statistics, Correlation analysis, and regression analysis. The finding showed that advertisements have a significant impact on consumers' buying behavior and choices.

Sunderaraj (2018)stated the research objective to study the impact of advertisements on buying behavior. It was found that there is no relationship between the age of the respondents and the level of impact of advertisement, and there was no relationship between income and satisfaction with the advertised product at the time of using.

Sama (2019) studied the effects of television (TV), radio, newspapers, magazines, and Internet advertisements on awareness, interest, conviction, purchase, and post-purchase behavior of consumers. The online survey method was applied for the study and collected data from students in India. Data were analyzed by Cronbach alpha, exploratory factoranalysis, and Kruskal-Wallis test, which showed that newspaper advertisements affect all the five stages of consumer behavior.

Gaudel, (2019)investigates the effects of social media networking in Nepalese consumer purchase decision by taking 150 observations from Kathmandu valley. The Data were analyzed by descriptive and causal-comparative research design. He found a significant relationship between online reviews, user trust, and information on social media and consumer purchasing decisions.

\section{Conceptual Framework}

The conceptual framework consists of price, brand, perceived quality, and perceived feature as independent variables and purchasing behavior as dependent variables. According to (Farzana, 2012; Işıklar \& Büyüközkan, 2007; Lay-Yee et al., 2013), purchasing decisions depends upon all independent variables.

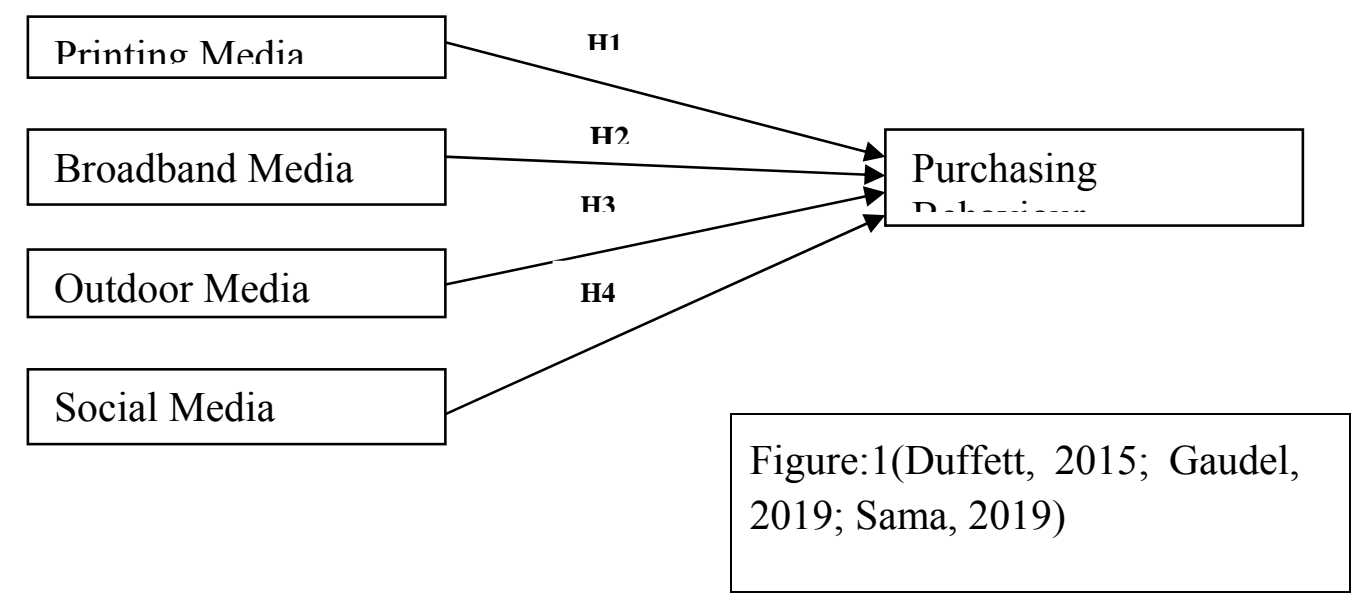




\section{Research Hypothesis}

H1: There is a significant relationship between print media and purchasing behavior $\mathrm{H} 2$ : There is a significant relationship between broadbandmedia and purchasing behavior H3: There is a significant relationship between outdoor media and purchasing behavior H4: There is a significant relationship between social media and purchasing behavior.

\section{Research Methodology}

The research work is fully based on primary data collection. The study has used a quantitative research design. The research philosophy is positivism. The descriptive and causal-comparative research design has been incorporated in this study. A descriptive research design gives the description of phenomena associated with a subject population. It helps to estimate the proportions of a population and discovers the relationships among different variables.

Similarly, causal-comparative relationship analysis how one variable affects or changes in another variable.It helps to examine the relationship between independent and dependent variables. A total of 150 samples were taken inside the Kathmandu Valley by a structured questionnaire. Data were obtained through simple random sampling techniques. The data collected from the survey were arranged, managed, tabulated, charted, analyzed, and interpreted in MS Excel, SPSS version 20, and MS Word according to the study's needs to attain the stated purposes. The data were analyzed by descriptive as well as inferential statistics. The tools that were used for interpretation were descriptive, correlation coefficient, regression, and alike were performed.

\section{Validity and Reliability}

Internal consistency coefficients (Cronbach's Alpha) were assessed to examine reliability factors. Nunnally (1978) has recommended 0.70 as the acceptable level for reliability. According to Hair, J. et al. (1998), the value of Cronbach's Alpha should be higher than 0.7, and it is regarded as asuitable value for measuring internal consistency. Table 1 shows that all values of Cronbach's Alpha in the study were more significant than 0.7 and indicate the good internal consistency of the constructs(Shakib, 2018).

Table 1: Cronbach's Alpha of different variables

\begin{tabular}{lc}
\hline Variables & Cronbach's Alpha \\
\hline Printing Media & 0.81 \\
Broadcasting Media & 0.79 \\
Outdoor Media & 0.78 \\
Social Media & 0.80 \\
Purchasing Behaviour & 0.83 \\
\hline
\end{tabular}


Table 1 shows Alpha values ranged from 0.78 to 0.83 , indicating an acceptable level of reliability. It was used todetermine the items' internal consistency (Ramiz et al., 2014). Sama also found Cronbach's alpha values were above 0.70(Sama, 2019).

\section{Results and Discussion}

The main aimisto identify the major influential factor of advertisements on consumer purchasing behavior. The demographics variables were discussed in terms of the consumer's gender, age, occupation, education level, and annual income status that are depicted in table 2.

Descriptive statistics were used to explain each construct by mean, standard deviation, minimum, and maximum for (Black, 2011).Five-point Likert scale was used to measure 15 items of print media, broadcasting media, and outdoor media,social media, and consumer purchasing behavior within the composite variables, with 5 representing "strongly agree" and 1 representing "strongly disagree."The correlation measures the strength of relationships, not causation. The correlation r-value always lies between -1 and +1 . A positive $r$-value explains a positive relationship, and a negative $r$-value describes a negative relationship between the variables. Regression was used to determine the nature and power of a mathematical relationship between one or more independent variables $(\mathrm{X})$ and a single dependent variable (Y)(Black, 2011).

Table 2: Frequency of Demographic Factor

\begin{tabular}{clcc}
\hline & Demographic Factor & Frequency & Percent \\
\hline \multirow{3}{*}{ Gender } & Male & 78 & 52 \\
& Female & 72 & 48 \\
& $15-24$ & 17 & 11.3 \\
& $25-34$ & 81 & 54 \\
& $35-44$ & 34 & 22.7 \\
& 45 and Above & 18 & 12 \\
\multirow{5}{*}{ Education } & No Formal Educated & 37 & 24.7 \\
& Secondary & 13 & 8.7 \\
& Higher Secondary & 16 & 10.7 \\
& Bachelors & 45 & 30 \\
& Master Degree and Above & 39 & 26 \\
Occupation & Student & 14 & 9.3 \\
& Private Jobholder & 73 & 48.7 \\
& Government Jobholder & 4 & 2.7 \\
& Businessperson & 21 & 14 \\
& Unemployed & 38 & 25.3 \\
Annual Income & Total & 150 & 100 \\
Status & Below 200000 & 81 & 54 \\
& 200000-300000 & 31 & 20.7 \\
\hline
\end{tabular}




$\begin{array}{ccc}300000-400000 & 8 & 5.3 \\ 400000-500000 & 8 & 5.3 \\ \text { Above } 500000 & 22 & 14.7\end{array}$

Table 2 shows out of 150 respondent's males were slightly higher than in females. The age group of 25-35 was higher respondents than other age groups. The bachelor's and master's degrees and above have great knowledge about advertising. Most of the respondents were private jobholders with $48 \%$ andbelow Rs. 2,00,000 annual income status respondents with 54\%(Lim et al., 2017; Sunderaraj, 2018).

Table 3: Average of Different independent and dependent variables

\begin{tabular}{lrrrr}
\hline Variables & Minimum & Maximum & Mean & Std. \\
Deviation \\
\hline Printing Media & 1.67 & 5 & 3.553 & 0.818 \\
Broadcasting Media & 1.67 & 5 & 3.477 & 0.791 \\
Outdoor Media & 1.33 & 5 & 3.277 & 0.877 \\
Social Media & 2.00 & 5 & 3.671 & 0.739 \\
Purchasing Behaviour & 1.67 & 5 & 3.520 & 0.836 \\
\hline
\end{tabular}

Table 3 shows that the mean scores of the composite variables in this study were between 3.277 and 3.671, which means that the respondents have average scores on most composite variables(Sunderaraj, 2018). These factors show that almost all respondents agree with the advertising media. Consumers purchasing behavior depends on different kinds of advertising media such as printing media, broadcasting media, outdoor media, social media. The standard deviations of the composite variables were between 0.739 and 0.877 . Similar observations were also reported in the literature (Sata, 2013).

Table 4: Correlation analysis among independent and dependent variables

\begin{tabular}{|c|c|c|c|c|c|}
\hline Correlations & $\begin{array}{c}\text { Printing } \\
\text { Media }\end{array}$ & $\begin{array}{c}\text { Broadcasting } \\
\text { Media }\end{array}$ & $\begin{array}{l}\text { Outdoor } \\
\text { Media }\end{array}$ & $\begin{array}{l}\text { Social } \\
\text { Media }\end{array}$ & $\begin{array}{l}\text { Purchasing } \\
\text { Behaviour }\end{array}$ \\
\hline Printing Media & 1 & & & & \\
\hline Broadcasting Media & $\begin{array}{c}.487 * * \\
0\end{array}$ & 1 & & & \\
\hline Outdoor Media & $\begin{array}{c}.523 * * \\
0\end{array}$ & $\begin{array}{c}.698^{* *} \\
0\end{array}$ & 1 & & \\
\hline Social Media & $\begin{array}{c}.502 * * \\
0\end{array}$ & $\begin{array}{c}.518^{* *} \\
0\end{array}$ & $\begin{array}{c}.555^{* *} \\
0\end{array}$ & 1 & \multirow{3}{*}{1} \\
\hline \multirow[t]{2}{*}{ Purchasing Behaviour } & $.430 * *$ & $.418 * *$ & $.470 * *$ & $\begin{array}{c}.472 * \\
*\end{array}$ & \\
\hline & 0 & 0 & 0 & 0 & \\
\hline $\begin{array}{l}\text { ** Correlation is signi } \\
\text { b Listwise } \mathrm{N}=150\end{array}$ & it the 0 & (2-taile & & $\mathrm{S}$ & \\
\hline
\end{tabular}


Table 4 shows the correlation relationship between dependent variable Consumer Purchasing behavior and independent variables printing media, broadcasting media, outdoor media, and social media. The above table shows there was a strong positive relationship between the dependent and independent variables and significant.Advertisement media helps to make a consumer purchase decision(Gaudel, 2019). Similarly, there is a positive relationship between "outdoor, printing and broadcasting media" and "Consumer purchase decision." They are significant at the 0.01 level.Shakib also reported a positive relationship between the independent variables and dependent variable consumer buying behaviour (Shakib, 2018).

Table 5: Model Summary

\begin{tabular}{cccccc}
\hline Model & $\mathrm{R}$ & R Square & $\begin{array}{c}\text { Adjusted R } \\
\text { Square }\end{array}$ & $\begin{array}{c}\text { Std. Error of } \\
\text { the Estimate }\end{array}$ & $\begin{array}{c}\text { Durbin- } \\
\text { Watson }\end{array}$ \\
\hline 1 & $.557 \mathrm{a}$ & 0.310 & 0.291 & 0.704 & 1.980 \\
\hline
\end{tabular}

a Predictors: (Constant), Social, Printing, Broadcasting, Outdoor Media

b Dependent Variable: Purchasing Behaviour

Table 5 shows the summary of regression analysis with regards to the dependent variable consumer purchasing behavior. The value of $\mathrm{R}$ square 0.310 meant that the selected variables explained only $31 \%$ of the change in purchasing behavior, whereas the rest 69\% was accounted for other variables(Shakib, 2018). The Durbin-Watson value 1.980 lay between $d_{u}$ to $4-d_{u}$, representing the area of no autocorrelation. So it revealed that there was no autocorrelation in the analysis.

Table 6: Analysis of Variance (ANOVA)

\begin{tabular}{clccccc}
\hline \multirow{2}{*}{ Model } & & Sum of & \multicolumn{3}{c}{ Mean } \\
Squares & Df & Square & F & Sig. \\
\hline \multirow{2}{*}{1} & Regression & 32.378 & 4 & 8.094 & 16.312 & $.000 \mathrm{~b}$ \\
& Residual & 71.951 & 145 & 0.496 & & \\
& Total & 104.329 & 149 & & & \\
\hline
\end{tabular}

a Dependent Variable: PurchasingBehaviour

b Predictors: (Constant), Social, Printing, Broadcasting, OutdoorMedia

Table 6 shows the analysis of variance (ANOVA) of regression analysis regarding the dependent variable purchasing behavior. The value of 'Sig.' was 0.000 , which was less then P-value 0.001. (Gaudel, 2019) analyzed consumer Buying Behaviour as a dependent variable and information in social media, advertisement in social media networking, user trust, and online review as an independent variable significant. The table shows that the 
independent variables statistically significantly predict the dependent variable, $F(4,145)$ $=16.312, p<0.05$. It concluded that the fitted model was statistically significant(Chukwu et al., 2019; Gaudel, 2019; Shakib, 2018).

Table 7: Coefficients

\begin{tabular}{|c|c|c|c|c|c|c|c|c|}
\hline \multirow[t]{2}{*}{ Model } & & \multicolumn{2}{|c|}{$\begin{array}{l}\text { Unstandardized } \\
\text { Coefficients }\end{array}$} & $\begin{array}{l}\text { Standardized } \\
\text { Coefficients }\end{array}$ & $\mathrm{t}$ & Sig. & \multicolumn{2}{|c|}{$\begin{array}{l}\text { Collinearity } \\
\text { Statistics }\end{array}$} \\
\hline & & B & Error & Beta & & & Tolerance & VIF \\
\hline \multirow{8}{*}{1} & (Constant) & 1.022 & 0.33 & & 3.095 & 0.002 & & \\
\hline & Printing & & & & & & & \\
\hline & Media & 0.174 & 0.088 & 0.17 & 1.988 & 0.049 & 0.648 & 1.543 \\
\hline & Broadcasting & & & & & & & \\
\hline & Media & 0.076 & 0.105 & 0.072 & 0.717 & 0.475 & 0.477 & 2.094 \\
\hline & Outdoor & & & & & & & \\
\hline & Media & 0.192 & 0.099 & 0.201 & 1.937 & 0.054 & 0.441 & 2.267 \\
\hline & Social Media & 0.269 & 0.100 & 0.238 & 2.696 & 0.008 & 0.612 & 1.635 \\
\hline
\end{tabular}

a Dependent Variable: Purchasing Behaviour

The results from the co-efficient table (Table -7) show the level of significance for each variable. The table shows that the printing media, outdoor media, and social media have a significant impact on purchasing behavior as the $\mathrm{p}$-value for all three independent variables is $\mathrm{p}<0.05$ (Gaudel, 2019; Shakib, 2018).The standardized Beta value shows that among the four independent variables, social media has the most significant impact, with $23.8 \%$, followed by outdoor media (20.1\%) printing media (17\%) and broadcast media (7.2\%).

The table also shows that there was not any kind of multicollinearity. The (VIF) variance inflation factor identified the correlation between independent variables and that correlation's strength. The value of VIF lay between 1.543 to 2.26 , representing, and there was no multicollinearity.

The variables employed in multiple regressions.

$\hat{\mathrm{Y}}=\alpha+b 1 X 1+b 2 X 2+b 3 X 3+b 4 X 4$

Where, $\hat{Y}$ is the dependent variable Purchasing Variable, and $\alpha$ is the intercept.

X1(Printing media), X2(Broadband media), X3(Outdoor Media), and X4(Social Media), were the independent variables, and $\mathrm{b} 1, \mathrm{~b} 2, \mathrm{~b} 3$ and, $\mathrm{b} 4$ were the coefficient of the independent variables.

The regression model is, therefore:

$\mathrm{Y}=a+\beta 1 \mathrm{X} 1+\beta 2 \mathrm{X} 2+\beta 3 \mathrm{X} 3+\beta 4 \mathrm{X} 4$ 


$$
\mathrm{Y}=1.022+0.174 \mathrm{X} 1+0.076 \mathrm{X} 2+0.192 \mathrm{X} 3+0.269 \mathrm{X} 4
$$

The coefficient estimate of the constant term of the regression was 1.022. It showed that what the value of the dependent variable was if all the independent variables became zero. It indicated that the purchasing behavior was changed by 1.022 units, given all the independent variables were zero(Shakib, 2018). The probability value (P-value) 0.000 was less than 0.05 . It indicated a model found to be statistically significant, but the slope coefficient of broadband media was found to be statistically insignificant.

\section{Conclusion}

The enormity and significance of the loading estimates show the vital role played by advertisements mediain affecting consumer purchasing behavior. Many constructs are taken to make the model fit. The main objective of this study is to examine the relationship between advertisement dimensions and consumer purchasing behavior. Results show that there exists a significant impact of advertisements on consumer buying behavior. Printing media, broadband media, outdoor media, and social media are taken as the dimensions of advertisements and consumer buying behavior taken as a dependent variable. As per the results, it is concluded that almost all respondents agree with the advertising that affects consumer purchasing behavior. The correlation value also indicates that there was a strong correlation between advertisement dimensions and consumer purchasing behavior.

The regression result revealed that there were no autocorrelation and no multicollinearity. It also indicated that printing, outdoor and social media were statistically significant, and broadband media was found to be statistically insignificant. There exist a significant positive relationship between print media, outdoor media, and social media as p-value is less than 0.05 in all. However, broadband media of advertisement dimension value is higher than 0.05 has an insignificant relationship.

\section{Limitations and Future Research}

First, all data were drawn from 150 respondents located at Kathmandu valley. The findings of the study may be improved if additional respondents will bring. Second, this study examined the relationship between variables by hypotheses based on cross-sectional data. It could not observe the dynamic change of advertisement media and consumer purchasing behavior in the different environmental regulations stages through longitudinal data. Therefore, future studies can set forth toward the longitudinal study to find out the significant Impact on Consumer purchasing behavior on the environmental regulations in the context of Nepal. 


\section{Acknowledgment}

The authors would like to thankPatan Multiple Campus, PatanDhoka, Lalitpur, Tribhuvan University for continuous encouragement, support, and necessary assistance.

\section{Reference}

Black, K. (2011). Business statistics for contemporary decision making.London: John Wiley and Sons.

Chukwu, B. A., Kanu, E. C., \& Ezeabogu, A. N. (2019). The Impact of Advertising on Consumers Buying Behaviour. International Journal of Arts and Commerce, 8(1), $1-15$.

Deshpande, M., Rokade, Y., \& Darda, P. S. (2019). The Impact of Advertisement on Consumer Buying Behavior in Electronic Industry. 4(12), 145-153.

Duffett, R. G. (2015). Facebook advertising's influence on intention-to-purchase and purchase amongst Millennials. Internet Research, 25(4), 498-526. https://doi.org/10.1108/IntR-01-2014-0020

Farzana, W. (2012). Consumers' Psychological Factors Association with Brand Equity of High-Involvement Product: Case of Laptop. World Journal of Social Sciences, 2(5), 369-391.

Gaudel, D. (2019). Effects of Social Media Networking on Consumer Purchase Decision in Nepal. SSRN Electronic Journal. https://doi.org/10.2139/ssrn.3485421

Hair, J., Anderson, R., Tatham, R. and Black, W. (1998). Multivariate data analysis. Prentice Hall, Inc,Upper Saddle River, New Jersey.

Işı1klar, G., \& Büyüközkan, G. (2007). Using a multi-criteria decision making approach to evaluate mobile phone alternatives. Computer Standards \& Interfaces, 29(2), 265274. https://doi.org/10.1016/j.csi.2006.05.002

Ismail, M. (2016). Effects of Advertisement on Consumer's Buying Behaviour with References to FMCGs in Southern Punjab-Pakistan. Journal of Marketing and Consumer Research, 19, 22-30.

Kotler, P., \& Keller, K. L. (2006). Marketing management (Twelfth ed). Pearson Prentice Hall.

Lay-Yee, K. L., Kok-Siew, H., \& Yin-Fah, B. C. (2013). Factors Affecting Smartphone Purchase Decision among Malaysian Generation Y. International Journal of Asian Social Science, 3(12), 2426-2440. 
Lim, X. J., Lim, X. J., Mohd Radzol, A. R. bt, (2017). The Impact of Social Media Influencers on Purchase Intention and the Mediation Effect of Customer Attitude. Asian Journal of Business Research, 7(2), 19-36. https://doi.org/10.14707/ajbr.170035

Nunnally, J. C. (1978). Psychometric theory. New York: McGraw-Hill.

Prasad, R. K., \& Jha, M. K. (2014). Consumer buying decision models: A descriptive study. International Journal of Innovation and Applied Studies, 6(3), 335-351.

Rajagopal. (2011). Impact of radio advertisements on buying behaviour of urban commuters. International Journal of Retail \& Distribution Management, 39(7), 480 503. https://doi.org/10.1108/09590551111144888

Ramiz, M., Qasim, M., Rizwan, M., Aslam, F., \& Khurshid, A. (2014). The Comparative Analysis of the Factors Effecting Brand Loyalty towards Samsung Products. Journal of Sociological Research, 5(1), 327-349. https://doi.org/10.5296/jsr.v5i1.6569

Sama, R. (2019). Impact of Media Advertisements on Consumer Behaviour. Journal of Creative Communications, 14(1), 54-68. https://doi.org/10.1177/0973258618822624

Sata, M. (2013). Factors Affecting Consumer Buying Behavior of Mobile Phone Devices. Mediterranean Journal of Social Sciences, 4(12), 103-112. https://doi.org/10.5901/mjss.2013.v4n12p103

Shakib, S. (2018). A Study on The Influences of Advertisement on Consumer Buying Behavior. 9(1), 1-13.

Sunderaraj, R. (2018). Impact of Advertisement on Buying Behaviour of Consumers in Sivakasi. Ictact Journal On Management Studies, 04(03), 800-808. 